Jurnal Ilmu Sosial dan Pendidikan (JISIP)

Vol. 6, No. 1 Januari 2022

e-ISSN : 2656-6753, p-ISSN: 2598-9944

DOI: 10.36312/jisip.v6i1.2829/http://ejournal.mandalanursa.org/index.php/JISIP/index

\title{
Upaya Pemberdayaan Petani Lahan Kering Untuk Mewujudkan Pertanian Berkelanjutan Dan Ketahanan Pangan
}

\author{
Petrus Ans Gregorius Taek ${ }^{1}$, Dedi Supriadi ${ }^{2}$, Stevendus Marten Taek $^{3}$ \\ ${ }^{1}$ Dosen Sosiologi Program Studi Ilmu Pemerintahan STISIP Fajar Timur Atambua \\ ${ }^{2}$ Dosen Ilmu Pemerintahan Universitas Teknologi Sumbawa \\ ${ }^{3}$ Fakultas Teologí-Universitas Pontifikal Comillas-Madrid-Spanyol.
}

\begin{tabular}{l}
\hline Article Info \\
\hline Article history: \\
Accepted: 06 Januari 2022 \\
Publish: 11 Januari 2022 \\
\\
\\
Keywords: \\
PPSE-KA Efforts, \\
Empowerment of Farmers, \\
Increase Production.
\end{tabular}

Info Artikel

Article history:

Diterima: 06 Januari 2022

Terbit: 11 Januari 2022

\begin{abstract}
Qualitative research using this case study method aims to describe the efforts of dry land farmers in Belu regency to maintain the volume of agricultural production through training and empowerment to be more resistant to erratic rainfall. KPSE-KA NTT in collaboration with CRS and YMTM is trying to empower farmers so that farmers are skilled in cultivating land in extreme weather conditions (Stress-Resilient). These efforts have contributed to assisting local governments in alleviating poverty due to agricultural products that are not profitable for farmers in areas with limited water availability. The results showed that the farmers formed in groups had increased their maize and beans production by more than $80 \%$. Target farmers have used farming practices that are stress-resilient (able to withstand environmental pressures) so that agricultural crops can survive despite limited water availability. In addition, the skills of farmers have improved and their knowledge in marketing agricultural products has become wider. Cadre farmers are capable of community organizing, leadership and group dynamics, cultivation and plant management practices, able to practice soil and water conservation technology, able to manage long-life vegetable and plant crops, able to make work plans to create a structure / system of soil and water conservation in their gardens, able to coordinate directly with related agencies (agriculture, food security, forestry, $B P B D)$ to obtain agricultural services and inputs.

\section{ABSTRACT}

Penelitian kualitatif dengan Metode Studi kasus ini bertujuan untuk mendeskripsikan upaya petani lahan kering di Kabupaten Belu dalam mempertahankan volume produksi pertanian meskipun dalam curah hujan yang tidak menentu melalui pelatihan dan pemberdayaan. KPSE-KA NTT bekerja sama dengan CRS dan YMTM berupaya memberdayakan petani agar petani terampil dalam mengolah lahan meskipun dalam keadaan cuaca ekstrim (stress-resilient). Upaya ini telah berkontribusi dalam membantu pemerintah daerah dalam mengentaskan kemiskinan akibat hasil pertanian yang tidak mendatangkan keuntungan bagi petani di daerah-daerah yang ketersediaan airnya terbatas. Hasil penelitian menunjukan bahwa petani yang terbentuk dalam kelompok telah meningkatkan produksi jagung dan kacang-kacangan lebih dari 80\%. Petani Sasaran telah menggunakan praktek-praktek bertani yang stress-resilient (mampu bertahan dalam tekanan lingkungan) sehingga tanaman pertanian tetap hidup meskipun ketersediaan air terbatas. Selain itu, keterampilan
\end{abstract}


petani semakin meningkat dan pengetahuan memasarkan produk pertanian semakin luas. Petani kader mampu dalam pengorganisasian masyarakat, kepemimpinan dan dinamika kelompok, budidaya dan praktek pengelolaan tanaman, mampu mempraktekan teknologi konservasi tanah dan air, mampu mengelola tanaman sayuran dan tanaman umur panjang, mampu membuat rencana kerja untuk membuat struktur/system konservasi tanah dan air di kebunnya, mampu berkoordinasi langsung dengan dinas terkait (Pertanian, Ketahanan Pangan, Kehutanan, BPBD) untuk mendapatkan pelayanan dan input pertanian.

This is an open access article under the Lisensi Creative Commons Atribusi-BerbagiSerupa 4.0 Internasional

(c) (†) (9)

\section{Corresponding Author:}

Petrus Ans Gregorius Taek,

Sosiologi Prodi Ilmu Pemerintahan Sekolah Tinggi Ilmu Sosial Dan Ilmu Politik Fajar Timur Atambua

Email: Petrusgregorius87@gmail.com

\section{PENDAHULUAN}

Wilayah administrasi Kabupaten Belu-NTT adalah kabupaten perbatasan dengan Negara Demokratik Timor Leste dengan total jumlah penduduk bermayoritas bekerja sebagai petani lahan kering, peternak, maupun petani lahan basah. Dari tahun 2012 sampai dengan Tahun 2021 masyarakat mengalami dampak perubahan iklim yang cukup buruk yang berdampak negatif pada hasil produksi pertanian maupun peternakan. Hasil yang rendah diakibatkan karena curah hujan yang tidak menentu dan musim panas yang berkepanjangan.

Dalam upaya mengatasi dampak perubahan iklim itu, perhatian berbagai pihak tentu akan menitikberatkan pada konservasi hutan supaya dapat menunjuang sektor pertanian dan sektor peternakan. Kedua sektor itu patut dijaga pemeliharaannya karena jika diamati sepintas proses mata rantainya, kedua sektor ini saling berkaitan satu sama lain. Dalam hal ini kebutuhan akan konsumsi 9 bahan pokok makanan rumah tangga di Indonesia juga berasal dari kedua sektor ini sehingga sangat penting untuk dikembangkan dalam berbagai upaya.

Perubahan cuaca yang cukup ekstrim dan sulit diperdiksi dan pola curah hujan yang tidak teratur, berpengaruh besar bagi kegiatan usaha tani dan terhadap kondisi rawan pangan (food insecure). Pola cuaca yang ekstrim ini memberikan dampak terhadap bencana banjir, longsor atau kekeringan. Petani menjadi kesulitan untuk memprediksi masa tanam hingga panen. Pola pertanian yang masih menggunakan pola lama, yaitu tebas bakar. Minimnya penerapan teknologi tepat guna untuk peningkatkan produksi pangan, turut memberi pengaruh terhadap kondisi ketahanan pangan keluarga.

Potret yang terjadi dalam beberapa tahun terakhir ini bahwa upaya peningkatan produksi pangan harus lebih mendapat perhatian serius dari berbagai pihak karena jika diterlantarkan maka lahan-lahan pertanian akan dibiarkan "tertidur" dan menjadi lahan tandus atau lebih buruk lagi para petani akan menjual lahannya sebagai modal untuk pergi merantau ke luar negeri. Kebiasaan menjual tanah-tanah pertanian ini lumrah terjadi jika masyarakat terbelit utang atau untuk modal usaha. Pemerintah perlu sekali serius menangani fenomena sosial ini dengan bermitra dengan para tokoh masyarakat, tokoh adat, tokoh agama, LSM-LSM terkait dalam menyadarkan masyarakat sehingga kemudian pemerintah tidak perlu bersusah payah menangani masalah kemiskinan yang disebabkan oleh budaya masyarakat itu. Sekiranya bangsa ini perlu sadar bahwa jika tanah pertanian dijual kepada orang asing maka niscaya kemiskinan akan menjadi masalah yang tidak akan selesai dituntaskan. 
Salah satu upaya yang sangat gencar digalakan oleh Gereja Katolik melalui Komisi Pengembangan Sosial Ekonomi-Keuskupan Atambua (KPSE-KA) adalah memberi perhatian berupa pelatihan kepada masyarakat miskin dan papah dengan memberdayakan mereka agar mereka terampil dan meningkat pengetahuannya dalam mengolah lahan-lahan pertaniannya. Meskipun Sebagian besar wilayah pastoral Keuskupan Atambua adalah wilayah dengan curah hujan yang sangat rendah, namun Gereja terus melakukan perubahan pada sektor pertanian dengan menggandeng LSM-LSM lokal yang berkecimpung di bidang pertanian.

Implelentasi proyek Sustainable Agriculture for Enhanced Resilience (SAfER) dalam bentuk pelatihan dan pemberdayaan ini difasilitasi oleh KPSE-KA Belu (Panitia Pengembangan Sosial Ekonomi-Keuskupan Atambua) dan Yayasan Mitra Tani Mandiri (YMTM) dan didukung penuh oleh Catholic Relief Service (CRS). Proyek SAfER mendapat dukungan dan kerja sama penuh dari Pemerintah Daerah Belu, melalui instansi terkait seperti Dinas Pertanian dan Perkebunan, Badan Ketahanan Pangan dan Penyuluh Pertanian, Dinas Kehutanan serta instansi terkait lainnya.

Upaya pelatihan dan pemberdayaan ini sangat penting dilakukan mengingat Sebagian besar wilayah/lokasi penelitian ini adalah kawasan pertanian yang sebagian besar adalah "lahan tidur" yang belum/tidak sama sekali digarap oleh pemiliknya, sementara kebutuhan akan pangan sangat urgen untuk segera ditanggulangi tanpa kompromi.

Penelitian ini bertujuan untuk menganalisis upaya Komisi Pengembangan Sosial EkonomiKeuskupan Atambua (KPSE-KA) bekerja sama dengan LSM CRS dan LSM YMTM dalam meningkatkan produksi tanaman pangan di bidang pertanian lahan kering dengan pelatihan dan pemberdayaan agar para petani lebih tahan terhadap tekanan lingkungan / iklim yang selalu berubah-ubah (praktek-praktek bertani yang stress-resilient (mampu bertahan dalam tekanan lingkungan)) sehingga tanaman pertanian tetap hidup meskipun ketersediaan air terbatas. Melalui pengembangan sektor itu diharapkan dapat meningkatkan hasil-hasil pertanian seperti jagung, kacangan-kacangan, sayur-sayuran dan padi sehingga ketersediaan pangan pada musim panceklik masih tetap tersedia dan masyarakat tidak perlu merasa khawatir dengan "musim kelaparan" yang melanda setiap tahun. Secara tidak langsung proyek pelatihan dan pemberdayaan ini berdampak juga pada upaya mengurangi jumlah petani prasejahtera atau dapat menjauhan mereka dari perangkap kemiskinan (deprivation trap) yang menurut definisi Robert Chambers (1987) dalam (Suyanto, 2013:12) bahwa deprivation trap itu terdiri dari lima unsur yaitu: 1) kemiskinan itu sendiri, 2) kelemahan fisik, 3) keterasingan atau kadar isolasi, 4) kerentanan dan 5) ketidakberdayaan. Kelima unsur ini seringkali saling berkait satu sama lain sehingga merupakan perangkap kemiskinan yang benar-benar berbahaya dan mematikan peluang hidup orang atau keluarga miskin. Proyek pelatihan dan pemberdayaan ini juga telah dapat juga membantu meringankan pekerjaan Pemerintah Daerah Kabupaten Belu dalam menyelesaikan persoalan petani dan mengentaskan masalah kemiskinan.

Peran KPSE-KA melalui kerja sama dengan LSM-LSM lokal dan Internasional sangat diharapkan sebagai mitra pemerintah dalam pembangunan Sumber Daya Manusia (SDM) sehingga upaya-upaya melerai masalah sosial terutama kemiskinan dapat terselesaikan dan dapat membawa dampak positif pembangunan bagi bangsa dan negara. Gereja Katolik melalui Komisi Pengembagan Sosial Ekonomi-Keuskupan Atambua (KPSE-KA) mencoba merangkul para petani dengan mendanai usaha-usaha tersebut sehingga potensi-potensi lokal dapat dikembangkan.

Lokasi/Wilayah fokus studi penelitian ini hanya pada salah satu desa di Kecamatan Lamaknen Selatan tepatnya di Desa Ekin- Kabupaten Belu-Provinsi NTT. Mengapa lokasi ini dipilih karena pertama, banyak terdapat petani prasejahtera yang rata-rata memiliki lahan pertanian \pm 1 hektar yang kurang diperhatikan pengelolaannya / tidak digarap sama sekali sehingga hasil pertaniannya sangat kecil. Kebanyakan keluarga-keluarga petani itu hanya mengolah lahannya hanya untuk kebutuhan subtitensi (kebutuhan / konsumsi dalam rumah tangga) saja, bukan untuk dijual ke pasar. Realitas ini sangat memprihatinkan sehingga perlu sekali dilakukan pelatihan dan 
pemberdayaan kepada para petani prasejahtera ini agar mereka dapat sadar dan terampil mengolah lahan pertaniannya sehingga mereka dapat keluar dari perangkap kemiskinan terutama dalam pemenuhan kebutuhan hidup sehari-hari.

Kedua, persoalan kemiskinan yang diakibatkan oleh struktur sosial, natural/alam dan kultur mengakibatkan para petani itu perlu sekali dilakukan upaya sosialisasi terus menerus oleh berbagai pihak yang berewenang sehingga mereka dapat sadar untuk menyelesaikan persoalan mereka sendiri secara mandiri. Pada umumnya karakteristik kemiskinan yang dialami para petani ini yakni kemiskinan struktural yakni akibat akses yang terbatas pada sektor pertanian, perkebuanan, pendidikan, lapangan pekerjaan, kepemilikan lahan (tanah) untuk usaha, politik dan SDM yang rendah sehingga mereka rentan sekali masuk ke dalam perangkap kemiskinan. Karena itu perlu sekali peran pemerintah dan LSM-LSM dalam mengakomodasi kebutuhan akan akses-akses tersebut sehingga persoalan paran petani ini tidak membatasi ruang geraknya.

Selama ini Pemerintah Kabupaten Belu melalui Dinas Pertanian dan Perkebunan telah banyak menganggarkan dana dalam bentuk bibit, pupuk dan alat-alat pertanian untuk membantu meringankan beban kerja mereka namun hasilnya belum memuaskan karena kurangnya kontrol/pendampingan yang tersistem / berkelanjutan sehingga berdampak pada hasil yang kurang memuaskan. Adapun program bantuan lain bagi petani ini seperti beras miskin (Raskin), Program Keluarga Harapan (PKH), Program Nasional Pemberdayaan Masyarakat (PNPM) Mandiri, Kredit Usaha Rakyat (KUR), bantuan pendidikan dan lain sebagainya tetapi masih saja banyak terdapat warga miskin. Sikap mental "enak / harap gampang" masyarakat terhadap pemerintah membuat mereka enggan bekerja keras. Pola pendampingan pemerintah yang bernuasa "proyek" (habis anggran, habis tanggung jawab) dinilai kurang efektif dan efisien dan tidak mampu menekan laju pertumbuhan masalah kemiskinan.

Kini Pemerintah Daerah Belu sedikit terbantu pekerjaannya berkat kerja sama bermitra melalui pendampingan yang bertahap dan berkelanjutan dengan sistem kontrol yang ketat dari KPSE, LSM CRS dan LSM YMYM bagi para petani sehingga dapat menaikkan volume produksi pertanain. Para petani mulai terampil mengolah lahan pertaniannya meskipun dalam keadaan lingkungan kering/persediaan air yang terbatas. Jumlah petani prasejahtera mulai berkurang karena hasil-hasil pertanian dapat dijual untuk kebutuhan rumah tangga hingga kebutuhan masa depan.

Sebelumnya telah ada studi penelitian tentang pemberdayakan petani perempuan Oleh (Arsini, 2016) melalui usaha ekonomi produktif agar para petani memiliki pengetahuan, pemahaman dan ketrampilan dalam pengelolaan dan manajemen usaha secara lebih mendalam. Meningkatnya kesadaran mengenai pembuatan rencana kerja yang terinci, pengorganisasian dan pembagian tugas yang jelas diantara anggota, pentingnya pengarahan dan pemberian motivasi serta pengawasan terhadap jalannya organisasi akan membuat organisasi atau kelompok usaha dapat berkembang dan bertumbuh. Disamping itu pengetahuan mengenai perlunya perjanjian dalam proses jual beli atau pemesanan barang, mengelola dana simpan pinjam serta pembukuan transaksi keuangan juga menjadikan pengelolaan usaha kelompok batik Tulis Sekar optimal. Pengembangan usaha melalui pemasaran dan promosi secara online juga sangat membantu keberlangsungan usaha dari kelompok usaha bersama (KUB) batik Tulis Sekar yang sebelumnya pemasaran masih sebatas pesanan dari pelanggan saja. Kesimpulan penelitian ini bahwa (1) Partisipasi peserta sangat baik dilihat dari jumlah peserta yang hadir. (2) pelatihan manajemen usaha, pembukuan sederhana dan perluasan pasar dapat meningkatkan kinerja usaha di masa yang akan datang. (3) Adanya kesesuaian materi dengan kebutuhan kelompok dampingan, seperti pembuatan kontrak kerja serta pengelolaan simpan pinjam bagi anggota, pembukuan transaksi-transaksi keuangan secara sederhana dan pembuatan rencana usaha, adanya respon yang positif dari peserta dalam rangka optimalisasi pengelolaan usaha ekonomi produktif di masa yang akan datang.

Penelitian yang dilakukan (Kusrinah et al., 2016) tentang pelatihan dan pendampingan pemanfaatan eceng gondok (eichornia crassipes) menjadi pupuk kompos cair untuk mengurangi 
pencemaran air dan meningkatkan ekonomi masyarakat Desa Karangkimpul- Kelurahan KaligaweKecamatan Gayamsari-Kotamadya Semarang menemukan bahwa Eceng gondok dikenal sebagai salah satu gulma yang memiliki kecepatan tumbuh yang tinggi sehingga berpotensi merusak lingkungan perairan. Keberadaan eceng gondok di perairan memiliki nilai penting tersendiri terkait dengan keberlangsungan ekosistem perairan yaitu sebagai produsen. Kegiatan pengabdian masyarakat itu bertujuan untuk memberikan pelatihan dan pendampingan pemanfaatan eceng gondok menjadi pupuk kompos cair untuk mengurangi pencemaran air dan meningkatkan ekonomi masyarakat Desa Karangkimpul. Lokasi pengabdian masyarakat merupakan daerah rawa yang banyak ditumbuhi eceng gondok. Pengabdian masyarakat yang telah ditempuh ini menitikberatkan pada bagaimana teknologi sederhana dan tepat guna dapat digunakan oleh masyarakat melalui pengolahan eceng gondok menjadi produk berupa pupuk kompos cair. Pembekalan yang diberikan kepada masyarakat berupa teori dan praktik pembuatan pupuk kompos, pengemasan dan strategi pemasaran produk. Produk pupuk kompos cair berbahan dasar eceng gondok diharapkan dapat mendukung kebutuhan pupuk nasional dan meningkatkan taraf hidup masyarakat Desa Karangkimpul.

Kemudian penelitian tentang peran Gereja dalam pengentasan kemiskinan seperti yang dilakukan oleh (Sumbung, 2012) yang menemukan bahwa Umat di Gereja Masehi Injil di Minahasa (GMIM) di Kota Tomohon, Sulawesi Utara diberdayakan dengan pengembangan UKM (Industri Kecil dan Menengah) pengolahan kelapa-kayu. Pola pengembangan pemberdayaan ekonomi yang dilakukan oleh GMIM adalah melalui BLPT (Training Center) Kaaten, telah berhasil dalam meningkatkan kesejahteraan umatnya. Dalam menjalankan usahanya, BLPT melibatkan setiap workfoce siswa drop-out dari sekolah atau tidak menyelesaikan sekolah tinggi sehingga berpotensi meningkatkan pendapatan masyarakat sekitar, mengurangi jumlah putus sekolah, meningkatkan pengembangan bisnis kreatif, mengurangi kemiskinan dan pengangguran dan meningkatkan pendapatan untuk kas GMIM.

Selain itu, studi yang dilakukan oleh (Istan, 2017) menemukan bahwa Agama Islam mengajarkan untuk mengentaskan kemiskinan melalui pemberdayaan ekonomi umat yang lemah. Islam memandang sumber daya manusia secara personal menjadi agen utama dalam memberdayakan ekonomi umat. Islam juga melihat bahwa pengentasan kemiskinan merupakan tanggung jawab kolektif, baik itu pemerintah, ulama dan masyarakat itu sendiri. Model pemberdayaan dibagi menjadi dua kelompok; yakni yang bersifat struktural dan yang bersifat kultural. Langkah struktural lebih ditekankan kepada lembaga khusus yang menanganinya agar berjalan dengan baik. Sedangkan langkah kultural lebih ditekankan pada individu, baik individu yang diharapkan menjadi salah satu subjek dan objek pengentasan kemiskinan dan pemberdayaan. Persoalan bagaimana membebaskan kaum fakir miskin dari kemiskinan dan bagaimana memberdayakan kehidupan ekonominya berkaitan erat dengan masalah pemanfaatan dan pendistribusian harta. Ketentuan ayat-ayat Al-Qureean yang berbicara tentang harta (māl, amwāl), 20, yang pertama berupa perintah dan anjuran dan yang kedua berupa larangan. Ada beberapa langkah yang ditempuh Al-Qureean dalam mengentaskan kemiskinan dan memberdayakan kaum fakir dan miskin, yaitu perintah bekerja, perintah memberi makan, perintah berinfak, perintah mengeluarkan zakat, pembagian ganimah dan fa'i, penetapan hukum waris, larangan riba, larangan monopoli (ihtikār) dan menimbun harta (iktināz).

Ada juga penelitian dari (Sriyana, 2013) yang menjelaskan tentang peran (Baitul Mal wat Tamwil) atau Baitul Mal dan Baitul Tamwil) BMT berbasis Syariat Islam dimana target atau sasaran dan skalanya pada sektor usaha mikro yang dapat mengurangi kemiskinan di Kabupaten Bantul, khususnya dari aspek peran BMT dalam meningkatkan pendapatan anggotanya. peran BMT terhadap peningkatan pendapatan masyarakat dalam rangka penurunan tingkat kemiskinan terutama disebabkan pada kegiatan-kegiatan yang bersifat sosial, pendidikan dan peningkatan motivasi 
bekerja. Keberadaan BMT ini memang sangat cocok sebagai pelopor dalam pembelajaran dan pengembangan sistem ekonomi Islam kepada masyarakat.

Dari sekian banyak temuan pelatihan dan pemberdayaan oleh berbagai lembaga sosial, peneliti juga menemukan cara pelatihan dan pemberdayaan di sektor pertanian dari lembaga agama (KPSE-KA) yang bekerja sama dengan LSM-LSM lokal dan internasional dalam menanggulangi masalah ketersedian atau ketahanan pangan masyarakat dengan cara meningkatkan hasil-hasil pertanian meskipun dalam kondisi lingkungan yang terbatas ketersediaan air dan cuaca yang buruk (kering/panas) (stress-resilient).

Penyelesaian masalah ketahanan pangan pertanian lahan kering di daerah-daerah pegunungan bisa diatasi yang penting pengalaman (skill), keterampilan pengetahuan petani dilatih sehingga mereka dapat mengolah lahan-lahan pertaniannya secara baik dan benar sehingga dapat menghasilkan produk-produk yang berkualitas dengan jumlah yang mencukupi kebutuhan. Dukungan Peran dan perhatian dari berbagai pihak yang bertanggungjawab sangat diperlukan karena berbicara soal ketersedian makanan bagi manusia adalah masalah bersama yang wajib diperbincangkan terus menerus baik di tingkat nasional dan internasional sehingga sirkulasi dinamika kehidupan manusia dalam berbagai aspek (Kesejahteraan, Sosial, Politik, Budaya, Kesehatan, Pendidikan, Keamanan) terus berjalan tanpa henti. Diharapkan penelitian ini akan semakin memperkaya penelitian yang sudah ada, dimana sektor pertanian selalu mendapat perhatian dari berbagai kalangan untuk dikembangkan. Sektor pertanian lahan kering di derah-daerah pegunungan yang tandus juga harus bisa menyumbangkan produk pangan yang bermutu/berkualitas dengan jumlah yang cukup sehingga masalah kelaparan karena kurangnya ketersediaan makanan tidak menjadi masalah berkepanjangan yang mengancam nyawa umat manusia.

\section{METODE PENELITIAN}

Pendekatan penelitian adalah kualitatif dengan metode studi kasus. Pelaksanaan penelitian ini pada awal Desember 2020 sampai akhir januari 2021. Lokasi penelitian ini terjadi di Kecamatan Lamaknen Selatan tepatnya di Desa Ekin - Kabupaten Belu - Provinsi Nusa Tenggara Timur dengan jumlah kelompok tani sebanyak 9, dimana total petani penerima manfaat program pelatihan dan pemberdayaan ini sebanyak 198 orang (Laki-Laki: 149 orang / 75 \%, Perempuan: 49 orang / $25 \%$ ). Teknik penentuan lokasi penelitian dilakukan dengan teknik purposive sampling yakni dengan menetapkan ciri-ciri khusus yang sesuai dengan tujuan penelitian sehingga diharapkan dapat menjawab permasalahan penelitian. Fokus penelitian yaitu pada upaya pelatihan dan pemberdayaan oleh KPSE, CRS dan YMTM terhadap para petani penerima manfaat program.

Cara memperoleh sumber data dengan mencari dan menentukan informan serta foto-foto kegiatan program pelatihan dan pemberdayaan. Teknik penentuan informan yaitu purposive sampling. Pengambilan informan dengan cara menetapkan ciri-ciri khusus yang sesuai dengan tujuan penelitian, yaitu informan yang terlibat langsung dalam kegiatan pelatihan dan pemberdayaan sehingga dapat memberikan informasi yang akurat. Informan yang dipilih ditentukan terlebih dahulu meliputi: Para Staf pengelola/Pengurus KPSE-KA, Para Staf pengelola/Pengurus LSM CRS dan Para Staf pengelola/Pengurus LSM YMTM, Para ketua dan anggota kelompok tani yang ikut terlibat dalam kegiatan pelatihan dan pemberdayaan.

Teknik pengumpulan data dilakukan dengan dokumentasi, rekaman arsip, wawancara mendalam, observasi langsung dan focus group discussion (FGD). Dokumentasi diambil dari dokumen-dokumen administratif, foto-foto, video kegiatan pelatihan dan pemberdayaan. Rekaman arsip diambil dari rekaman layanan di sekretariat kantor KPSE-KA, rekaman keorganisasian seperti bagan dan anggaran, peta dan bagan karakteristik geografis dan data survei seperti rekaman data sensus. Wawancara mendalam dilakukan dengan mewawancarai para informan dan para petani yang ikut terlibat. Observasi langsung dan FGD dilakukan dengan para Staf/Pengurus PSE-KA, 
Para Staf pengelola/Pengurus LSM CRS dan Para Staf pengelola/Pengurus LSM YMTM, Para ketua dan anggota kelompok tani.

Pengujian keabsahan data dengan metode: a) Credibility (Derajat Kepercayaan) diselesaikan dengan cara: Perpanjangan pengamatan, Peningkatan ketekunan dalam penelitian, Trianggulasi (Trianggulasi sumber, Trianggulasi teknik, Analisis kasus negative, Menggunakan bahan referensi, Mengadakan member-cheek) b) Transferability (Derajat Keteralihan), c) Dependability (Derajat Ketergantungan) dan d) Confirmability (Derajat Kepastian). Pengolahan data dilakukan dengan pengecekan kebenaran data, menyusun data, melaksanakan penyandian (coding), mengklasifikasi data, mengoreksi jawaban wawancara yang kurang jelas untuk memudahkan tahap analisis. (Mudjia Rahardjo, 2017)

Teknik analisis data adalah analisis deskriptif berupa uraian tentang upaya pelatihan dan pemberdayaan oleh KPSE, CRS dan YMTM terhadap para petani penerima manfaat program dan penjelasan tentang program-program pemberdayaan yang berkaitan dengan pertanian. Langkahlangkah anlisis data yang digunakan adalah Analysis Interactive Model dari Miles dan Huberman yaitu pengumpulan data (data collection), kondensasi data (data condentation), penyajian data (data display) dan penarikan kesimpulan atau verifikasi (conclutions).

\section{HASIL PENELITIAN}

Sebelum masuk kepada penjelasan atau gambaran pelatihan dan pemberdayaan kepada para petani di Desa Ekin, perlu diketahui bahwa latar belakang profil atau desain pelaksanaan Program SAfER ini secara umum adalah untuk menjawabi masalah kurangnya produksi pangan sebagai akibat dari perubahan iklim dan curah hujan yang tidak menentu di Kabupaten Belu / (Petani lebih tahan terhadap curah hujan yang tidak menentu) (Farmers are more resilient to erratic rainfall). Kabupaten Belu dengan wilayah geografis yang bergunung, memiliki lahan-lahan pertanian yang tandus karena rendahnya ketersediaan air. Sebagian besar lahan pertanian dirancang dalam bentuk terasering untuk menahan air hujan sehingga air tetap bertahan dalam jangka waktu 2-3 hari. Dalam keadaan terbatas itu para petani dipaksa untuk tetap melakukan kegiatan pertanian sehingga dapat terus bertahan hidup.

Perlu diketahui juga bahwa fokus atau strategi proyek SafER adalah untuk memperkuat ketahanan petani/keluarga terhadap curah hujan yang tak menentu yang mempengaruhi usaha tani dan ketersediaan pangan di tingkat rumah tangga. Proyek ini telah menerapkan berbagai strategi dan kegiatan untuk meningkatkan ketersediaan pangan mendorong petani mendapatkan manfaat atas pengelolaan air yang baik (konservasi lahan dan air) dan peningkatan kapasitas petani untuk mengurangi resiko curah hujan yang tak menentu pada usaha tani yang dilakukan.

Sasaran strategis proyek yaitu membangun kapasitas dan ketrampilan petani untuk meningkatkan praktek pertanian yang tahan terhadap tekanan lingkunan (dari tanam sampai penyimpanan). Berdasarkan beberapa hasil assessment, konsultasi dengan Dinas Pertanian Belu dan beberapa mitra bahwa ada dua jenis tanaman yang menjadi prioritas yaitu jagung dan kacang hijau. Kedua jenis tanaman pangan itu sebagian besar tumbuh di wilayah-wilayah sasaran proyek yang mana sebagian besar lahan pertaniannya berbukit curam/pegunungan dengan ketersediaan air yang sangat terbatas. Pada umumnya aktivitas pertanian di wilayah ini ramai dikerjakan pada saat musim penghujan saja sedangkan pada musim kemarau semua petani beralih profesi dimana mereka akan bermigrasi ke kota atau merantau untuk mencari pekerjaan lain. Input pelatihan yang diberikan berkaitan dengan kedua jenis tanaman itu serta tanaman lokal lainnya akan memberikan manfaat yang besar bagi masyarakat. Kegiatan utama proyek SafER yaitu berupa pelatihan bagi petani untuk meningkatkan teknik budidaya jagung dan kacang hijau serta tanam lokal unggulan lainnya dan pelatihan bagi petani untuk peningkatan panen dan pasca panen-pengelolaan hasil panen termasuk metode penyimpanan yang baik sesuai adat istiadat atau budaya masyarakat setempat. 
Diversifikasi sistem tanam adalah untuk meningkatkan ketersediaan pangan dan mengurangi resiko melalui penanaman beberapa tanaman lokal yang tahan terhadap tekanan lingkungan. Petani dilatih untuk menanam beberapa varian tanaman baik sayur, kacang-kacangan dan jagung untuk menghindari ketergantungan pada salah satu jenis tanaman karena tantangan asumsi gizi yang dibutuhkan manusia sangat beragam dan prospek kebutuhan pasar sangat bervariasi. Strategi ini termasuk beberapa aktivitas utama berupa pelatihan dan dukungan teknis kepada petani dalam budi daya tanaman yang tahan terhadap tekanan lingkungan, pelatihan budidaya sayuran dan uji coba adaptasi dan kecocokan tanaman yang tahan terhadap tekanan lingkungan dengan agrositem lokal.

Proyek ini telah mempromosikan praktek pertanian dan teknologi yang mengoptimalkan input lokal yang tersedia (seperti kotaran sapi untuk pupuk, tanaman pelindung yang berkualitas). Hal ini tidak hanya akan membuat masyarakat lebih mandiri namun juga mengurangi ketergantungan mereka terhadap input ekternal yang mahal dan tidak berkelanjutan. Dalam strategi ini, kegiatan yang telah dilakukan mencakup: pelatihan bagi petani tentang pembuatan pupuk organik dan pestisida organik dengan memanfaatkan sumber daya lokal yang tersedia.

Tujuan strategis proyek ini adalah untuk meningkatkan produksi pangan di kalangan petani lahan kering dan meningkatkan diversifikasi tanaman melalui praktek-praktek konservasi tanah dan air oleh petani sasaran. Perubahan iklim yang sulit diprediksi 10 tahun terakhir ini mengakibatkan produksi pertanian tak menentu. Terkadang meningkat dan bisa juga berkurang sehingga perlu sekali dilakukan pelatihan kepada para petani agar bisa bertahan dalam kondisi tidak menentu itu. Proyek konservasi air dengan reboisasi hutan dengan menanam pohon-pohon yang mampu menyimpan air (Pohon Bambu, Mahoni, Kemiri, Gamal, Lantoro dan lain sebagainya) penting sekali dilakukan sehingga ketersediaan air tanah tetap terjaga meskipun musim kemarau terjadi. Konservasi ini dilakukan secara berkelompok maupun mandiri di lahan milik kelompok maupun di lahan pribadi dimana bibit pohon difasilitasi oleh Dinas Kehutanan dan Perkebunan Kabupaten Belu.

Durasi proyek ini selama 25 bulan, dimulai sejak: 1 Oktober 2017 dan berakhir pada 1 November 2019 yang telah melibatkan hampir seluruh masyarakat Desa Ekin. Masyarakat merasa terbantu sekali dengan adanya proyek SAFER ini karena dampak ekonomi dan sosial yang mereka dapatkan telah merubah kehidupan mereka dan pembangunan desa mereka. Secara ekonomis pendapatan perkapita rumah tangga mereka terbantu karena hasil pertanian yang dijual dapat digunakan untuk keperluan dapur rumah tangga dan juga bisa disisihkan untuk biaya pendidikan. Lalu lintas atau mobilisasi barang dan jasa yang ramai menjadi keuntungan tersendiri bagi warga desa tetangga yang juga mencari manfaat ekonomi dengan menjajakan barangbarang pelengkap pertanian. Sementara secara sosial kemasyarakatan terjadi interaksi sosial yang beragam dengan penduduk desa lain yang dapat berdampak pada meluasnya jaringan pemasaran hasil hasil pertaniannya. Modal sosial dapat berkembang dan terus meluas melalui interaksi sosial itu.

Data target proyek ini menyasar pada 1500 petani (30\% adalah petani wanita) di 4 Kecamatan dan 10 Desa seperti terinci dalam table 1 berikut:

Tabel 1. Lokasi Target Kelompok Tani Penerima Manfaat

\begin{tabular}{|c|l|l|}
\hline No & Kecamatan & Desa \\
\hline 1. & Tasifeto Barat & Derokfaturene \\
\hline 2. & Kakuluk Mesak & Leosama \\
\hline 3. & Lamaknen & Dirun \\
\hline & & Leowalu \\
\hline & & Fulur \\
\hline & & Duarato \\
\hline 4. & Lamaknen Selatan & Nualain \\
\hline & & Ekin \\
\hline
\end{tabular}




\begin{tabular}{|l|l|l|}
\hline & & Loonuna \\
\hline & & Sisifatuberal \\
\hline & & Lutharato \\
\hline
\end{tabular}

Para petani dilatih dengan kegiatan-kegiatan utama yang mendukung seperti konservasi tanah dan air, pelatihan pengurangan resiko bencana melalui pengolahan lahan pertanian yang tahan terhadap perubahan iklim, praktek menggunakan pupuk dan pestisida organik untuk kegiatan pertanian. Program SAfER juga memberi perhatian juga pada masalah DRR (Disaster Risk Management). Penguatan kapasitas petani dalam menghadapi masalah perubahan iklim dan curah hujan yang tidak menentu yang berdampak pada kegiatan pertanian.

PPSE Keuskupan Atambua sebagai pelaksana utama proyek tidak bekerja sendirian dengan maksud ada transparansi dan pengawasan pihak lain, cara yang ditempuh adalah dengan melibatkan pihak lain. Demi kelancaran proyek ini PPSE-KA memerlukan bantuan dari pihak lain sebagai mitra dengan menggandeng Yayasan Mitra Tani Mandiri (YMTM) (Pendamping teknis) LSM Catholic Relief Services (CRS INDONESIA) (pendonor utama proyek). Pemerintah Kabupaten Belu (Dinas Pertanian, Dinas Kehutanan dan Badan Ketahanan Pangan) untuk dukungan teknis, informasi, bibit TUP dan pendampingan.

\section{Analisa Capaian}

Dari berbagai macam kegiatan pelatihan dan pemberdayaan program SafER yang telah dilaksanakan selama 2 tahun (1 Oktober 2017 - 1 November 2019) memberikan berbagai perubahan dan dampak secara langsung kepada petani dan masyarakat desa. Capaian-capaian tersebut dapat digambarkan sebagai berikut;

Pada pelatihan pembentukan dan pengaktifan kembali kelompok tani, dilakukan identifikasi dan pembentukan kembali kelompok tani yang sudah pernah dibentuk. Sebelum proyek SafER dilaksanakan, telah terbentuk kelompok tani yang sudah dibentuk oleh Pemerintah Desa Ekin untuk kepentingan proyek tertentu dan setelah proyek tersebut selesai kelompok tani pun bubar dan keberlanjutan pekerjaan yang sudah dilakukan tidak jelas hasil dan nasibnya. Sejak awal, Program SAfER berkomitmen untuk tidak membentuk kelompok tani yang baru. Bila di desa sudah ada kelompok tani, maka hanya dibenahi kelompok tani yang sudah ada. Jika ada kelompok tani yang tidak aktif maka peran Pendamping Lapangan (PL) harus melakukan restrukturisasi pangurus dan keanggotaan kelompok tani. Setelah itu baru dilakukan identifikasi kelompok. Dari identifikasi tersebut terbentuklah atau diaktifkan kembali 9 kelompok tani, dimana 1 kelompok jumlahnya bervariasi 15-25 orang, total petani penerima manfaat program pelatihan dan pemberdayaan ini sebanyak 198 orang (Laki-Laki: 149 orang / 75 \%, Perempuan: 49 orang / $25 \%$ ). Identifikasi dan pengaktifan kembali kelompok tani itu penting sekali dilakukan sehingga dapat dipetakan kekuatan dan pekerjaan apa yang hendak dikerjakan sehingga jelas mekanisme pertanggungjawabannya dan berapa banyak target capain yang akan diperoleh. Dari sinilah titik awal dimulailah pelaksanaan proyek ini.

Tabel 2. Daftar Anggota Kelompok Tani Desa Ekin

\begin{tabular}{|c|c|c|c|c|c|c|}
\hline \multirow{2}{*}{ No. } & \multirow{2}{*}{ Kelompok } & \multirow{2}{*}{\begin{tabular}{c}
\multirow{2}{*}{ Jumlah } \\
Anggota
\end{tabular}} & \multirow{2}{*}{ Dusun } & \multicolumn{2}{|c|}{$\begin{array}{c}\text { Jumlah Yang } \\
\text { Didata }\end{array}$} & \multirow{2}{*}{ Keterangan } \\
\cline { 5 - 7 } & & & Sudah & Belum & \\
\hline 1. & Malolo & 24 & Ekintas & 19 & 5 & 5 Orang Anggota Baru \\
\hline 2. & KWT Mekar Sari & 20 & Ekintas & 12 & 8 & 8 Orang Anggota Baru \\
\hline 3. & Mutiara & 16 & Bianlai & 16 & 0 & Selesai \\
\hline 4. & KWT Bunda Sejati & 20 & Ekintas & 16 & 4 & 4 Orang Anggota Baru \\
\hline 5. & Sinar Harapan & 16 & Bianlai & 7 & 9 & 9 Orang Anggota Baru \\
\hline 6. & Mandiri & 23 & Koin & 21 & 2 & 2 Orang Anggota Baru \\
\hline
\end{tabular}




\begin{tabular}{|c|c|c|c|c|c|c|}
\hline 7. & KWT Jati Diri & 25 & Ekintas & 25 & 0 & Selesai \\
\hline 8. & Tini Rimil & 24 & Koin & 22 & 2 & 2 Orang Anggota Baru \\
\hline 9. & Sinar Dilibul & 30 & Aitameak & 26 & 2 & 2 Orang Anggota Baru \\
\hline & Total & 198 & & 164 & 32 & \\
\hline
\end{tabular}

Setelah pengidentifikasian dan pengaktifan kembali kelompok tani dilakukan kegiatan pertemuan umum kelompok tani di tingkat desa pada tahun pertama 2018, pertemuan umum kelompok dilakukan sebanyak 6 kali pertemuan melibatkan 120 petani. Dalam pertemuan itu selain membahas kegiatan kelompok tani di tingkat desa juga dilakukan sinkronisasi dengan beberapa program lain seperti PNPM sehingga tidak terjadi tumpang tindih program dan bongkar pasang anggota kelompok tani. Pertemuan bulanan ini sudah tidak asing lagi bagi masyarakat desa karena mereka sebelumnya telah banyak melakukan pertemuan untuk membahas proyel-proyek pemerintah yang pernah dilaksanakan. Dinamika diskusi kelompok berjalan lancar dimana semua anggota berpartisipasi aktif dalam menyumbang ide demi keberhasilan Proyek Safer. Dampak dari kegiatan pengaktifan kembali ini adalah terjadinya peningkatan motivasi dan semangat para petani dalam bergotong-royong. Hal ini dapat dilihat dari jumlah anggota kelompok yang cukup banyak dan mereka dapat melakukan kerja bersama meskipun dalam beban kerja yang berat.

Setelah pengaktifan kelompok tani, dilakukan pelatihan dan pengembangan sayuran dengan penerapan teknologi konservasi air yang melibatkan sebanyak 120 petani dimana mereka menanam sayur menggunakan teknologi bedeng dan olah lubang. Kedua teknologi ini sangat cocok dan mudah diterapkan oleh petani. Para petani yang menanam sayur menggunakan teknologi itu merasa lebih mudah atau terbantu pekerjaanya karena sayur yang ditanam tumbuh subur dan masa panennya lebih cepat serta dapat dipanen beberapa kali. Contoh di salah satu kelompok tani, Sayur Ketimun yang ditanam dapat dipanen lebih dari 18 kali, hasil penjualan Sayur Ketimun mencapai Rp. 18 juta. Keberhasilan teknologi konservasi air ini berkat kerja keras semua anggota kelompok yang dibuktikan dengan terus dilakukan penanaman kembali Pohon Bambu, Mahoni, Jati, Kemiri, Gamal, Beringin, Tebu Hutan dan lain sebagianya. Air tanah kembali mengalir karena rimbunnya pepohonan. Irigasi tetes juga dibuat untuk terus meneteskan air di bedeng-bedeng sayur dan tanaman jagung. Peralatan seperti galon / fiber 5.000 liter dan selang ukuran 3 Dim yang diberi lubang-lubang halus sepanjang 200-an meter dihubungkan dengan fiber penuh air kemudian dibiarkan mengalir setiap menit sehingga tanaman tetap segar meskipun cuaca dalam keadaan panas terik.

Telah diadakan juga pelatihan teknis Konservasi Tanah dan Air dan pengelolaan demplot bagi staf PPSE, PPL, Mantri Tani \& Koordinator PPL. Dimana pelatihan itu dilakukan sebanyak 1 kali melibatkan peserta 19 orang (10 staf PPSE-KA dan 9 orang dari PPL Pemerintah). Setelah itu, dilakukan pelatihan pendampingan membuat rencana tindak lanjut pelatihan ke tingkat kelompok tani yang difasilitasi LSM CRS. Melalui pelatihan ini berdampak siknifikan pada pengetahuan dan pengalaman PL maupun PPL dimana mereka dapat melakukan pendampingan secara baik kepada petani dalam penerapan teknologi KTA baik di demplot maupun di kebun petani. Para pendamping kelompok yang sebelumnya belum pernah terlibat dalam pendampingan kelompok tani di daerah kering dan tandus dapat menularkan ilmu pelatihan itu para petani di lokasi kebun yang letaknya jauh dari sumber air. Dengan bantuan peralatan yang difasilitasi oleh LSM CRS seperti air tangki, galon fiber 5.000 liter dan selang ukuran 3 Dim sepanjang 200-an meter maka kegiatan pelatihan itu dapat berjalan baik dan selanjutnya fasilitas irigasi tetes itu diberikan kepada para petani untuk melancarkan pekerjaan mereka. Dampak dari pelatihan dan pemberian fasilitas ini terlihat jelas pada hasil panen kebun sayur petani yang cukup tinggi dan telah dijual di pasar-pasar tradisonal.

Telah terjadi kegiatan pelatihan penerapan teknologi terasering dan olah lubang (Demplot) di kebun petani yang dilakukan dalam bulan Agustus-September 2018 di 12 kelompok tani di lokasi 
kebun yang berbeda-beda. Sudah nampak teras dan olah lubang di kebun petani. Jumlah teras yang dikerjakan sudah mencapai 18.748 meter yang tersebar di 8 kelompok dampingan. Sedangkan teknologi olah lubang merupakan teknologi yang paling banyak dikerjakan petani pada budidaya tanaman sayur dan jagung. Jumlah olah lubang yang dikerjakan mencapai 15.764 lubang. Teknologi olah lubang dilakukan dengan cara tanah digali membentuk lubang dengan diameter 10$20 \mathrm{~cm}$, kedalaman $\pm 20 \mathrm{~cm}$ dengan jarak antar lubang $\pm 50 \mathrm{~cm}$ kemudian diberi pupuk kendang berupa kotoran sapi atau kambing yang sudah kering. Tanaman yang ditanam pada lubang bervariasi seperti sayuran, Lombok/Cabai Merah, Tomat dan bisa juga Jagung. Para petani yang lokasi kebunnya berada di atas bukit lebih banyak membuat olah lubang dari pada terasering karena cara pembuatannya lebih mudah dan durasi pembuatannya lebih cepat. Tanaman yang ditanam lebih aman terlindungi dari panas. Dampak dari pelatihan ini yaitu varian tanaman yang tanam lebih banyak dan tanaman lebih bagus dalam pertumbuhannya karena lubang yang dibuat dapat menampung air dan terhindar dari panas terik matahari. Pertumbuhan tanaman lebih cepat dan hasilnya lebih bagus dengan jumlah yang cukup banyak.

Terjadi pelatihan pembuatan pupuk dan pestisida organik dimana pembuatan pupuk dan pestisida organik mengalami perkembangan yang luar biasa. Pembuatan pupuk organik memacu anggota kelompok tani untuk mengembangkan tanaman sayuran dalam jumlah banyak. Pemanfaatan pupuk dan pestisida organik yang sesuai dengan dosis dan diberikan tepat waktu dapat membuat sayur cepat dipanen. Selama ini petani yang menanam sayur hanya menggunakan pupuk kimia sehingga membutuhkan biaya besar dengan efek mengganggu kesuburan tanah. Penggunaan pupuk organik semakin mendorong petani untuk menanam sayur lebih dari 1 kali pada tempat yang sama dengan menggunakan teknologi olah lubang dan bedengan.

Dalam kegiatan pelatihan pengembangan demplot sebagai tempat belajar bagi petani berdampak pada ditanamnya banyak varian sayuran. Demontrasi plot (demplot) sebagai model pendekatan yang sangat efektif karena melalui demplot petani dapat belajar langsung tanpa harus memberikan penjelasan yang lebih banyak dalam pengelola demplot. Jumlah demplot yang dikerjakan dalam tahun pertama sebanyak ribuan demplot dengan jenis tanaman yang dikembangkan yakni jagung, kacang hijau, talas dan pisang. Rata-rata luas demplot dari semua kelompok dampingan sekitar 119 are. Penempatan kebun demplot di lokasi yang strategis memberikan pengaruh yang besar bagi petani di desa karena ketika petani melewati kebun demplot tersebut maka secara otomatis petani sudah belajar dari demplot tersebut. Pembuatan demplot ini cukup sederhana saja karena dengan melihat secara kasat mata saja, petani sudah bisa merancang sendiri dan membuatnya di kebunnya sendiri tanpa perlu pendampingan dari Pendamoing Kelompok. Dimana lahan kebun yang sudah dibuat terasering selanjutnya dibuat lubang-lubang kecil berdiameter $\pm 10-20 \mathrm{~cm}$ dengan kedalaman $\pm 20-30 \mathrm{~cm}$ dan jarak $\pm 50 \mathrm{~cm}$.

Dilakukan juga Pelatihan tentang budidaya sayur yang bisa bertahan di tanah kering dimana pelatihan itu dilaksanakan sebanyak 52 kali melibatkan 198 orang (Laki-Laki: 149 orang / 75 \%, Perempuan: 49 orang / $25 \%$ ). Hasil pelatihan budidaya sayur membawa perubahan besar bagi petani. Buktinya seluruh kelompok tani yang mengembangkan tanaman sayur-sayuran menggunakan teknologi yang diberikan secara mandiri tanpa menunggu Pendamping Lapangan. Jenis sayur yang dikembangkan yang tahan kering yakni tomat, terung dan lombok.

Setelah terjadi beberapa kegiatan yang banyak menyita waktu dan tenaga, selanjutnya dilakukan pertemuan semesteran dan tahunan bagi petani sasaran dimana pertemuan semesteran pada bulan April 2018 melibatkan seluruh petani sasaran SAfER sebanyak 198 petani dan pertemuan tahunan pada bulan Oktober 2018. Pertemuan ini membawa pembelajaran yang berharga bagi petani karena petani bisa membuat perencanaan dan menyusun jadwal kerja kelompok tani secara bersama. Dalam pertemuan ini petani melakukan sharing pengalamannya dan evaluasi dalam menerapkan teknologi yang diberikan selama 1 tahun program. Kendala mengenai kesibukan petani akibat banyak kegiatan sosial dan adat istiadat di desa dapat diatasi dengan disepakatinya jadwal 
kerja bersama, bahkan ada rencana untuk menetapkan satu hari dalam seminggu bagi kelompok tani untuk bekerja secara bergotong-royong di salah satu kebun kelompok. Setelah dilakukan pertemuan evaluasi ini para petani mulai sadar dan bersemangat kembali untuk terus bekerja keras mempertahankan hasil kebunnya.

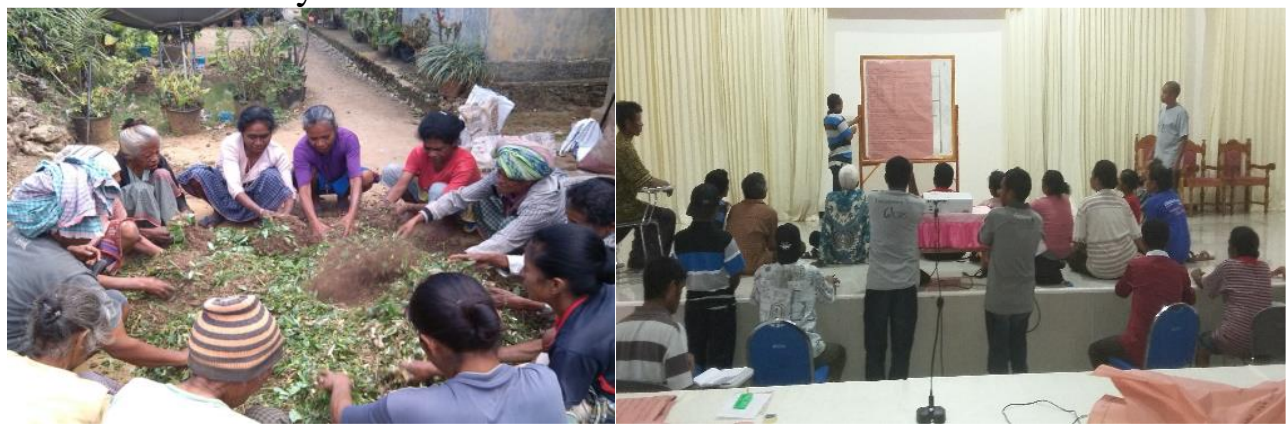

$(1 \mathrm{~A})$

(1 B)

Gambar 1 A. Praktek pembuatan Pupuk Bokasi. Gambar 1 B. Pertemuan dan pengidentifikasian serta pengaktifan kembali kelompok tani

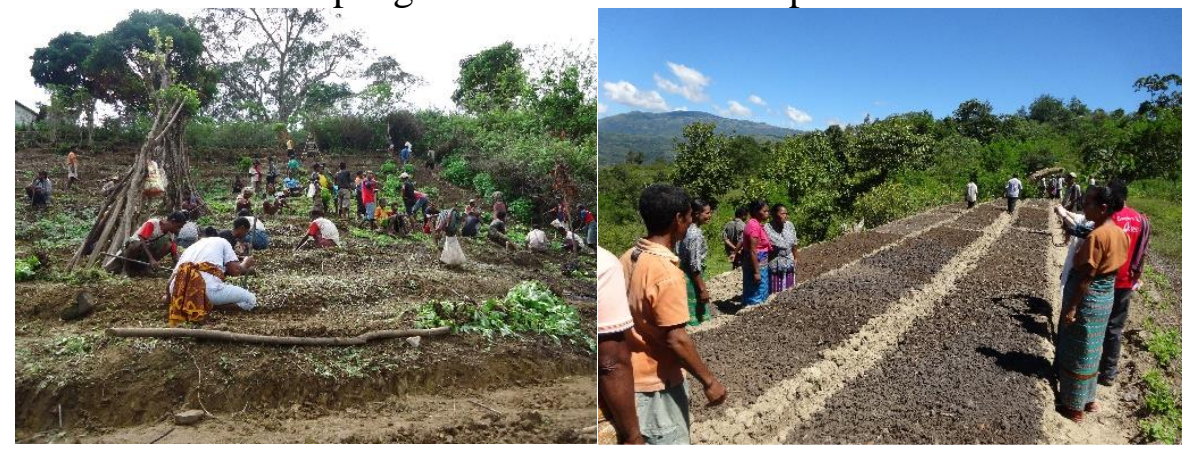

(2 A)

(2 B)

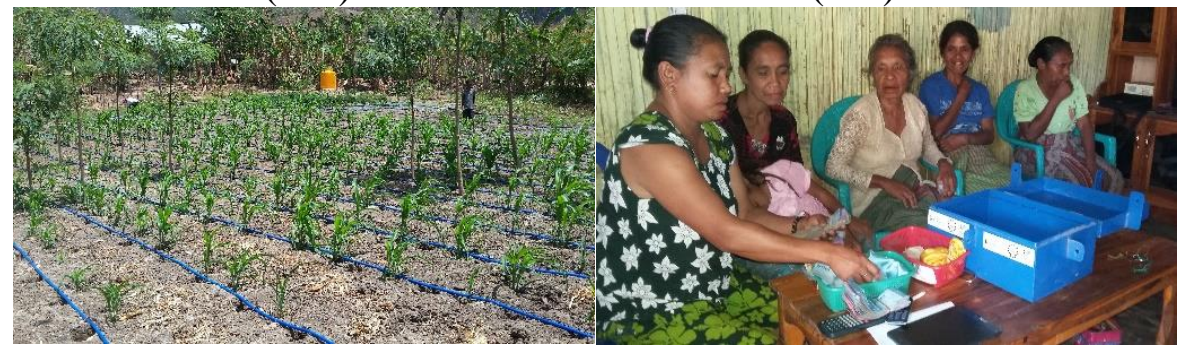

$(2 \mathrm{C})$

(2 D)

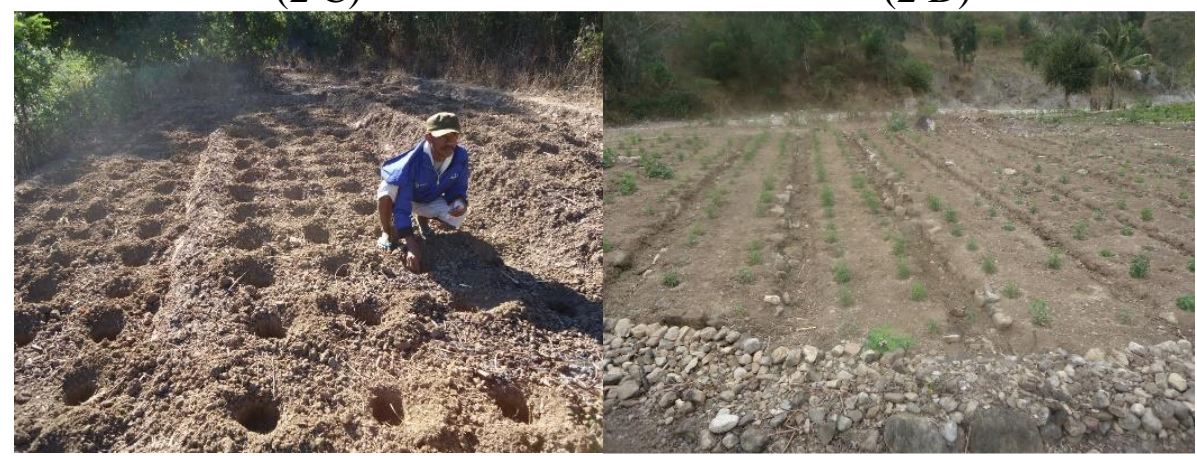

$(2 \mathrm{E})$

(2 F)

Gambar 2 A Pembuatan Teras. Gambar 2 B Pembuatan Demplot Sayur. Gambar 2 C Kebun Jagung Irigasi Tetes. Gambar 2 D Kegiatan Simpan Pinjam oleh ibu-ibu. Gambar 2 E Penerapan Teknologi Olah Lubang (Demontarasi Plot / Demplot). Gambar 2 F Tanaman Lombok yang sudah tumbuh dalam lubang. 


\section{Tantangan dan Solusi}

Beberapa aksi yang dilakukan untuk mengatasi tantangan dan hambatan yang dialami kelompok tani yakni:

Ada tumpang tindih program dapat mengganggu aktifitas kelompok tani. Upaya untuk mangatasinya yakni melakukan koordinasi dan kerjasama dengan kepala desa dan pihak lain untuk melakukan sinkronisasi program sehingga saling melengkapi.

Masih ada PPL yang kurang maksimal melakukan pendampingan kepada kelompok tani. Upaya yang dilakukan yakni membangun koordinasi dan komunikasi dengan pihak terkait sehingga bisa melakukan pendampingan secara baik, selain itu perlu membagi peran dan tanggunga jawab antara staf PPSE dengan PPL dalam melakukan pendampingan terhadap kelompok tani.

Kebakaran liar membuat tanaman terbakar dan kering. Upaya untuk mangatasinya dengan menegakkan kembali aturan desa dan sanksi adat serta memberikan peran kepada Makleat (Para tokoh adat). Upaya yang lain yakni membuat pagar hidup di batas kebun atau mengelilingi kebun sehingga tanaman bebas dari kebakaran.

Kekurangan air untuk mengembangkan tanaman sayur di beberapa kelompok. Upaya yang dilakukan untuk mengatasi hal itu yakni dengan melakukan penghijauan dan penanaman tanaman seperti pandan Hutan, Bambu, Tebu Hutan, Jambu Air dan Beringin di sumber mata air. Membuat sumur resapan pada sumber mata air agar dapat menampung air ketika hujan.

Kelompok tani terbentuk bermotivasi hanya untuk mendapat bantuan. Upaya untuk mangatasinya dengan memberikan pemahaman kepada anggota kelompok tani supaya berkelompok untuk membantu diri sendiri lewat kerjasama di antara anggota. Menata kelompok secara baik sehingga bisa berkompetisi jika ada dukungan dari pihak lain kepada kelompok tani.

Sistim pengelolaan kebun secara tradisional membuat tanah menjadi kritis \& berbatu. Upaya untuk mengatasinya dengan: (1) Mengolah lahan dengan menerapkan teknik konservasi tanah dan air seperti: membuat terasering, olah lubang, olah jalur, pembumbunan bahan organik, pengembangan Tanaman Umur Panjang (TUP) di setiap kebun anggota kelompok tani. (2) Menata kebun tetap. (3) Melakukan kunjungan belajar ke daerah yang berhasil mengembangkan teknologi konservasi tanah dan air.

Penggunaan pupuk \& pestisida kimia secara berlebihan. Upaya yang dilakukan untuk mengatasi hambatan ini: (1) Membuat kompos dan bokasi dan selalu memberikan informasi ke petani tentang bahaya penggunaan pupuk dan pestisida kimia (2) Melakukan demontrasi tentang bahaya pupuk dan pestisida kimia bagi kesehatan manusia.

Terjadi longsor pada lahan pertanian. Upaya yang dilakukan untuk mengatasinya dengan menanam tanaman Tebu Hutan, Bambu, Beringin, Pandan Hutan, Cemara, Jambu Air di daerah rawan longsor.

Partisipasi anggota kelompok tani menurun (pertemuan \& kerja kelompok). Upaya yang dilakukan untuk mengatasi hambatan itu dengan melakukan pendekatan secara individu/personal dan menggali secara detail mengenai ketidakhadiran anggota kelompok tani pada pertemuan atau kegiatan kelompok tani. Selain itu membuat pertemuan untuk mengaktifkan kembali yang pasif.

Masih ada ternak yang merusak kebun. Upaya yang dilakukan untuk mangatasinya dengan membuat pagar hidup dari batang Gamal pada batas kebun dan memberlakukan kembali sanksi adat.

Tingginya kagiatan sosial dan adat istiadat masyarakat yang mengganggu kerja kelompok. Upaya yang dilakukan untuk mengatasinya: (1) Membatasi diri untuk hadir pada acara sosial tersebut atau hanya mengutus salah anggota keluarga untuk menghadiri acara tersebut. (2) Bersama pemerintah desa menetapkan hari kerja tetap kelompok tani.

Banyak tenaga kerja produktif yang merantau ke daerah lain. Upaya yang dilakukan yakni melakukan identifikasi data keanggotaan kelompok tani, memberi motivasi dan membangun kesadaran pentingnya bekerja di desa sendiri melalui usaha pertanian. Berkoordinasi dengan 
pemdes untuk membuka lapangan kerja bagi tenaga produktif seperti meubeler atau memberikan lahan pertanian bagi kaum muda.

Program SAfER hanya berlangsung 2 tahun. Upaya yang dilakukan yakni: (1) Memberi peran kepada PPL untuk tetap mendampingi kelompok tani secara periodik 2 kali sebulan sehingga anggota kelompok selalu mendapat informasi teknis dari PPL. Kader petani dapat meneruskan kegiatan teknis yang sudah dipelajari bersama kelompok tani. (3): Pengetahuan dan ketrampilan yang diperoleh harus tetap dilanjutkan untuk kesejahteraan petani itu sendiri.

Sebagian anggota kelompok berumur lanjut usia. Upaya yang dilakukan untuk mengatasinya: Anggota kelompok tani yang berumur lanjut usia hanya dilibatkan dalam kegiatan pengembangan tanaman sayuran dan prosesing pasca panen.

Walupun ada tantangan yang besar bagi anggota kelompok tani namun ada beberapa peluang dan kesempatan yang perlu dimanfaatkan oleh kelompok tani sehingga kelompok bisa berkembang dengan baik seperti; 1) ada kelompok tani yang tidak bubar sesaat setelah program selesai, 2) kader petani yang selalu membantu dan respon terhadap program pertanian, 3) ada ADD yang dialokasikan untuk kelompok tani, 4) petani memiliki lahan yang luas (memiliki 3-4 bidang/KK), 5) ada tenaga pendampingan teknis dari PL dan PPL, 6) tersedia benih lokal di desa, 7) sering dilakukan uji coba teknologi baru, 8) peluang pasar yang terbuka, 9) sudah memiliki pengetahuan dan keterampilan KTA, 10) tersedia sarana transportasi. Kesempatan dan peluang sebagai hasil dari proyek SafEr ini perlu dikembangkan selalu sehingga selesai proyek ini masyarakat Desa Ekin tetap terus hidup melalui skil-skil yang sudah diajarkan.

Rencana kerja yang perlu mendapat perhatian khusus untuk proyek berikutnya adalah pendampingan teknis pembuatan KTA (terasering, olah lubang, olah jalur, jebakan air), pembuatan pupuk dan pestisida organik, pengembangan tanaman sayuran, pertemuan kelompok pada tingkat kelompok tani dan tingkat desa, pelatihan lanjutan bagi kader petani, penghijauan sumber mata air dan daerah rawan longsor, membangun kerjasama dengan dinas terkait untuk keberlanjutan kelompok tani, penataan kebun impian dan pembuatan Poster, brosur dan video.

\section{KESIMPULAN DAN SARAN}

Dari seluruh kegiatan pelatihan dan pemberdayaan yang terjadi dapat disimpulkan bahwa masyarakat Desa Ekin secara keseluruhan dan secara khusus para petani yang tergabung dalam kelompok tani sangat tanggap terhadap perubahan sosial, bahwa mereka ingin agar kehidupan mereka sedikit lebih baik dengan berupaya sebisa mungkin untuk keluar dari perangkap kemiskinan. Dapat dibuktikan bahwa para petani telah memperoleh manfaat dan pengetahuan serta pengalaman seperti peningkat pengetahuan dalam pengorganisasian masyarakat, kepemimpinan dan dinamika kelompok; budidaya dan praktek pengelolaan tanaman yang tahan dalam tekanan lingkungan; peningkatkan pengetahuan dan keterampilan dalam teknologi dan praktek konservasi tanah dan air, pengelolaan tanaman sayuran dan tanaman umur panjang (TUP), dapat membuat rencana kerja untuk membuat struktur/sistemkonservasi tanah dan air di kebun, mampu berkoordinasi langsung dengan dinas terkait (Pertanian, Ketahanan Pangan, Kehutanan, BPBD) dalam mendapatkan pelayanan dan input pertanian. Semua pengalaman belajar yang diperoleh dari pelatihan dan pemberdayaan itu sangat bermanfaat yang dapat digunakan sebagai modal sosial untuk saling mendukung dalam upaya melerai masalah kemiskinan.

Terimakasih kepada semua pihak (PPSE-KA, LSM CRS, LSM YMTM, Pemerintah Desa Ekin dan Masyarakat Desa Ekin) yang telah mengorbankan kesempatan, waktu dan tenaga serta modal tambahan yang tak terduga sehingga proyek pertanian ini dapat berhasil dalam meningkatkan pangan dan mengentaskan kemiskinan.

\section{DAFTAR PUSTAKA}

Arsini, A. (2016). Pemberdayaan Petani Perempuan Dalam Usaha Ekonomi Produktif Untuk 
Mengatasi Pengangguran Musiman Dan Mengurangi Kemiskinan Di Desa Putat Purwodadi Grobogan. Dimas: Jurnal Pemikiran Agama Untuk Pemberdayaan, 14(1), 87-100. http://journal.walisongo.ac.id/index.php/dimas/article/view/400

Istan, M. (2017). Pengentasan Kemiskinan Melalui Pemberdayaan Ekonomi Umat Menurut Persfektif Islam. 2(1).

Kusrinah, K., Nurhayati, A., \& Hayati, N. (2016). Pelatihan dan Pendampingan Pemanfaatan Eceng gondok (Eichornia crassipes) Menjadi Pupuk Kompos Cair Untuk Mengurangi Pencemaran Air dan Meningkatkan Ekonomi Masyarakat Desa Karangkimpul Kelurahan Kaligawe Kecamatan Gayamsari Kotamadya Semarang. Dimas: Jurnal Pemikiran Agama Untuk Pemberdayaan, 16(1), 27. https://doi.org/10.21580/dms.2016.161.890

Mudjia Rahardjo. (2017). STUDI KASUS DALAM PENELITIAN KUALITATIF: KONSEP DAN PROSEDURNYA. In Journal of Personality and Social Psychology (Vol. 1, Issue 1). https://doi.org/10.1111/j.1469-7610.2010.02280.x

Sriyana, J. (2013). Peran BMT Dalam Mengatasi Kemiskinan Di Kabupaten Bantul. 7(1), 29-50.

Sumbung, G. dkk. (2012). Peran Gereja Dalam Peningkatan Ekonomi Masyarakat Di Tomohon Sulawesi Utara. 15(4), 8-14.

Suyanto, B. (2013). Anatomi kemiskinan dan strategi penanganannya: fakta kemiskinan masyarakat pesisir, kepulauan, perkotaan dampak dari pembangunan di Indonesia. Intrans Publishing. 